\title{
Isolation and Characterization of Lactic acid bacteria from homemade fermented foods for probiotic applications
}

\author{
T. Sivasankari Devi ${ }^{{ }^{*}}$, B. Jeberli Prabina ${ }^{2}$, M. Gomathy ${ }^{2}$ and K. Kumutha ${ }^{3}$ \\ ${ }^{1}$ Assistant professor (Agri. Microbiology), Tamil Nadu Rice Research Institute \\ Aduthurai, India \\ ${ }^{2} A C \&$ RI, Killikulam, India \\ ${ }^{3} A C \&$ RI, Madurai, India \\ *Corresponding author
}

\section{A B S T R A C T}

\section{Keywords}

Probiotics, Lactic acid bacteria, fermentation, bile salt. $\mathrm{pH}$ tolerance

Article Info

Accepted:

08 January 2020

Available Online:

10 February 2020
The study was conducted with the aim of isolating efficient probiotic lactic acid bacteria from traditional fermented foods viz., curd, pickle and Idly batter. A total of five lactic acid bacteria were isolated from the above mentioned naturally fermented homemade foods. Morphological and cultural characterization of the isolates revealed that they were gram positive both cocci and bacilli type having shiny straw yellow colonies and were further characterized. All the five isolates were able to utilize lactose and dextrose as a sole carbon sources. Among the LAB isolates C- 1 was exhibiting the high level of inhibition zone $(10 \mathrm{~mm})$ against tested pathogenic Escherichia coli culture. The LAB isolates were tested for tolerance to $\mathrm{pH}$ and bile salt. The LAB isolate $\mathrm{P}-2$ were showing growth at all the tested $\mathrm{pH}$ ranges $(\mathrm{pH} 2.0,3.0$ and 4.0). None of the tested LAB isolates showing tolerance to both 3 and $5 \%$ bile salt concentration.

\section{Introduction}

Lactic acid bacteria (LAB) are a group of Gram-positive, non-spore forming, cocci or rod shaped microorganisms. Food industries have exploited these bacteria for thousands of years for the production of fermented foods. These bacteria are having ability to produce desirable changes in taste, flavour and texture of the fermented foods. Also produces antimicrobial substances such as lactic acid, acetic acid and bacteriocins and are generally known to inhibit food borne pathogens and spoilage microorganisms, thereby extending the shelf-life and enhancing the safety of food products.

Isolation and screening of microorganisms from natural sources has always been the most powerful means for obtaining useful and genetically-stable strains for industrially important products. Lactic Acid Bacteria 
(LAB) are important in the food and diary industries because the lactic acid and other organic acids produced by these bacteria act as food preservatives as well as flavour enhancers. Lactic Acid Bacteria (LAB) find increasing acceptance as probiotics which aid in stimulating immune responses, preventing infection by entero-pathogenic bacteria, treating and preventing diarrhoea. Lactic acid fermentation as a means of food preservation is probably one of the oldest 'biotechnological processes' rooted in the cultural history of mankind.

Probiotics are defined as "Live microorganisms when administrated in adequate amounts confer a health benefit on host" (FAO/WHO, 2011). Most probiotics available today belong to genera Lactobacillus and Bifidobacterium. LAB are most important group of microorganisms used in food fermentation, they contribute to the fast and texture of fermented products and inhibit food spoilage and pathogenic bacteria by producing antimicrobial substances (lactic acid, hydrogen peroxide, bacteriocin) (Phillip et al ., 2012).

Several mechanisms by which probiotics mediates their health benefits on the host have been suggested, and can be divided in to three categories: (i) certain probiotics have antibacterial activity and can exclude or inhibit pathogens; (ii) probiotics bacteria can enhance the intestinal epithelial barrier; (iii) probiotics bacteria are believed to modulate host immune response (Lebeer et al., 2010).

To perform their effect in the intestine probiotics bacteria should be capable of surviving passage through gastro intestinal tract (GIT).Thus it is essential for bacteria to have protection systems to withstand the low $\mathrm{pH}$ in the stomach, digestive enzymes and bile of the small intestine (Jensen et al., 2012). LAB were successfully isolated from curd samples (Ghosh et al., 2011). The present study is focused on the isolation and characterization of LAB from naturally fermented homemade foods and to determine their probiotics potential.

\section{Materials and Methods}

\section{Isolation of lactic acid bacteria from fermented foods}

LAB were isolated from the fermented foods viz., curd, pickle and Idly batter using $10^{-3}$ to $10^{-5}$ dilutions with saline, plated on to MRS (de Mann Rogosa Sharpe) agar and incubated at $37^{\circ} \mathrm{C}$ for $2-3$ days. Five well isolated colonies from each sample were picked up and transferred to MRS broth. Colonies were propagated twice and streaked on MRS agar to check the purity of the isolates and then stored in MRS soft agar $(0.5 \%)$ overlaid with glycerol at $-20^{\circ} \mathrm{C}$.

\section{Carbohydrate fermentation test}

Fermentative degradation of various sugars such as lactose, dextrose, maltose, galactose and sucrose were carried out in a fermentation tube. A fermentation tube is a culture tube that contains a Durham tubes (i.e., a small tube placed in an inverted position in the culture tube) for the detection of gas production, as an end product of metabolism.

The fermentation broth contains the ingredients of nutrient broth, a specific carbohydrate and a $\mathrm{pH}$ indicator (phenol red), which is red at a neutral $\mathrm{pH}(7)$ and turns yellow at or below a $\mathrm{pH}$ of 6.8 due to the production of organic acid.

All the 5 LAB isolates namely $\mathrm{C}-1, \mathrm{P}-1, \mathrm{P}-2$, I-1 and I-2 were inoculated in the fermentation test tubes and incubated at $28 \pm 2^{\circ} \mathrm{C}$ for $24-48 \mathrm{hrs}$. Observation was taken on change in colour and production of acid. 


\section{Probiotic properties of isolates anti- microbial activity}

All the 5 LAB isolates namely $\mathrm{C}-1, \mathrm{P}-1, \mathrm{P}-2$, I-1 and I-2 were inoculated into MRS broth and incubated at $37^{\circ} \mathrm{C}$ for $24 \mathrm{hrs}$. The cultures were evaluated for antimicrobial activity against Escherichia coli by cross streak method. Zone of inhibition of $E$. coli was visually observed and resistance was scored and expressed as positive and negative which indicates the ability to kill E. coli or not.

\section{Resistant to low pH}

Resistance to $\mathrm{pH} 2,3$ and 4 are often used in invitro assays to determine the resistance to stomach $\mathrm{pH}$. Food usually stays in the stomach for 3-4 hours and this time limit was taken into account. All the $5 \mathrm{LAB}$ isolates namely C-1, P-1, P-2, I-1 and I-2 were grown for 16 - 18 hours in MRS broth. The cells were centrifuged at $5,000 \mathrm{~g}$ for $10-15 \mathrm{~min}$ at $4^{\circ} \mathrm{C}$ and the pellet collected in a sterile tube. The pellet was washed twice with phosphate saline buffer (PBS at $\mathrm{pH}$ 7.0) and inoculated in MRS broth adjusted to $\mathrm{pH} 3.0$ (by addition of $1 \mathrm{M} \mathrm{HCl}$ ) and incubated at $37^{\circ} \mathrm{C}$. Viable microorganisms were enumerated at the 0,1 , 2, 3 and 4 hours by recording the absorbance at $660 \mathrm{~nm}$ in spectrophotometer. Lactobacillus plantarum strains were more aciduric than the other species as all strains could grow at $\mathrm{pH} 4.0$ (Papamanoli et al., 2003).

This correlates well with the results reported by Hugas et al., 1993. L. plantarum strains used as starter culture in the manufacture of dry fermented sausages may give rise to a product will an over acidities, which is not well excepted by the consumers (Garriga et al.,1996). Although some L. curvatus strains could display as much as acidity as $L$ .plantarum, there are some important sensorial descriptors (Garriga et al., 1996).

\section{Tolerance against bile salts}

The mean intestinal bile concentration is believed to be $0.3 \%(\mathrm{w} / \mathrm{v})$. The staying time of food in small intestine is suggested to be 4 hrs. The experiment was applied at this concentration of bile for $4 \mathrm{hrs}$. MRS medium containing 3 and $5 \%$ bile salt was inoculated with active cultures (16 - $18 \mathrm{hrs}$ old cultures) of 5 LAB isolates namely C-1, P-1, P-2, I- 1 and I-2. During the 4 hrs incubation at 3 and 5 $\%$ bile, viable colonies were enumerated for every hour by recording the absorbance at 660 $\mathrm{nm}$ in spectrophotometer.

\section{Results and Discussion}

\section{Isolation and characterisation of Lactic acid bacteria}

Lactic acid bacterial cultures were isolated from different fermented foods viz., curd, pickle and Idly batter. The results of cultural and morphological characters for the five isolates namely $\mathrm{C}-1, \mathrm{P}-1, \mathrm{P}-2, \mathrm{I}-1$ and $\mathrm{I}-2$ were presented in Table 1. All the five isolates were positive for Gram's reaction. The shape varies from coccus to bacilli (rod). All the isolates from curd and pickle were producing shiny, straw yellow colour colonies and the rest colonies were opaque and dull white.

\section{Carbohydrate fermentation test for LAB isolates}

All the five isolates were tested for growing or utilizing different carbon sources for growth and development. All the isolates were utilizing dextrose by producing acid, except the isolate (P- 2), all other isolates were utilizing maltose. Lactose was utilized by all except C-1, P-1, P-2. Only one isolate namely $\mathrm{P}-1$ were utilizing galactose and none of the isolate able to utilize sucrose. The isolates were easily utilizing the monosaccharides than the disaccharides. 
(Table 2). LAB isolates were exhibiting both cocci and bacilli type, all were gram positive cultures showing similarity with other Lactic acid bacteria. Carbohydrate fermentation test revealed that, all the organisms were able to utilize Lactose as a sole carbon source and also able to utilize the other sugars viz., maltose, dextrose, galactose and sucrose.

Lactobacilli were the most prevalent organisms isolated from MRS agar plates. (Papamanoli et al., 2003). Strains of Lactobacillus sakei and Lactobacillus curvatus have been shown to predominate in various fermented meat products (Samelis et $a l ., 1994)$. They are the best candidates to be used as started cultures for dry sausage production, since they were proved highly competitive during fermentation (Hammes et al., 1998).

\section{Antimicrobial activity against Escherichia coli}

The isolates were tested for its ability to control or exhibit antimicrobial activity against Escherichia coli. The results were presented in (Table 3). All the five isolates were showing some extend of antimicrobial activity. The activity was measured and expressed as zone of inhibition in $\mathrm{mm}$.
Among all isolates C-1 was exhibiting the high level of inhibition $(10 \mathrm{~mm})$ followed by I-1 lowest inhibition zone was registered by I$2, \mathrm{P}-1$ and P-2. The antimicrobial activity of the LAB isolates were tested against the intestinal pathogen Escherichia coli.

All the isolates were able to exhibit some extend of antimicrobial activity against $E$. coli. Since, all the isolates able to produce antibacterial proteins, which could able to kill $E$. coli, which is the important characters for the probiotic organisms, for to live in the intestinal region of human beings (Papamanoli et al., 2003).

\section{Screening of LAB isolates to different acidity pH 3.0}

The ability of withstanding low acid level was tested for all the five isolates ( $\mathrm{pH}$ range: 3.0 and 4.0). The results were recorded for $0,1,2$, 3, $4 \mathrm{~h}$ and presented in the Figure 1 and 2.

The isolate $\mathrm{P}-2$ recorded the highest growth followed by $\mathrm{C}-1$ and $\mathrm{I}-1$. lowest was recorded by I-2 (0.042) at 4 hours of incubation. (Figure.1). Same trend was observed at $\mathrm{pH}$ 4.0 also. Lowest was observed in I-2 (0.043) at 4 hours of incubation (Figure.2).

Table.1 Morphological and cultural characteristics of LAB isolates from fermented foods

\begin{tabular}{|c|c|c|c|c|c|}
\hline $\begin{array}{c}\text { LAB } \\
\text { Isolates }\end{array}$ & Sample & $\begin{array}{c}\text { No. of colonies } \\
(\mathbf{C F U x 1 0} / \mathbf{g})\end{array}$ & $\begin{array}{c}\text { Grams } \\
\text { Reaction }\end{array}$ & Shape & Colony characters \\
\hline $\mathbf{C - 1}$ & Curd & 4 & + & Coccus & shiny, straw yellow \\
\hline $\mathbf{P - 1}$ & Pickle & 7 & + & Coccus & shiny, straw yellow \\
\hline $\mathbf{P - 2}$ & Pickle & 5 & + & Coccus & shiny, straw yellow \\
\hline $\mathbf{I - 1}$ & Idly batter & 8 & + & Bacilli & Opaque, dull white \\
\hline I-2 & Idly batter & 11 & + & Bacilli & Opaque, dull white \\
\hline
\end{tabular}


Table.2 Carbohydrate fermentation test for LAB isolates from fermented foods

\begin{tabular}{|c|c|c|c|c|c|c|c|c|c|c|}
\hline LAB & \multicolumn{2}{|c|}{ Lactose } & \multicolumn{2}{c|}{ Dextrose } & \multicolumn{2}{c|}{ Maltose } & \multicolumn{2}{c|}{ Galactose } & \multicolumn{2}{c|}{ Sucrose } \\
\hline Isolates & Acid & Gas & Acid & Gas & Acid & Gas & Acid & Gas & Acid & Gas \\
\hline C -1 & - & - & + & - & + & - & - & - & - & - \\
\hline P -1 & - & - & + & - & + & - & + & - & - & - \\
\hline P -2 & - & - & + & - & - & - & - & - & - & - \\
\hline I -1 & + & - & + & - & + & - & - & - & - & - \\
\hline I -2 & + & - & + & - & + & - & - & - & - & - \\
\hline
\end{tabular}

Table.3 Screening of LAB isolates for antimicrobial activity against Escherichia coli

\begin{tabular}{|c|c|}
\hline LAB isolates & Antimicrobial assay (Inhibition zone) $\mathbf{m m}$ \\
\hline C-1 & 10 \\
\hline P-1 & 5 \\
\hline P-2 & 5 \\
\hline I-1 & 9 \\
\hline I-2 & 6 \\
\hline
\end{tabular}

Table.4 Screening of LAB isolates for tolerance to bile salt (3\%)

\begin{tabular}{|l|c|c|c|c|c|}
\hline LAB Isolates & $\mathbf{0 ~ h}$ & $\mathbf{1 ~ h}$ & $\mathbf{2 ~ h}$ & $\mathbf{3 ~ h}$ & $\mathbf{4} \mathbf{~ h}$ \\
\hline Control & 0 & 0 & 0 & 0 & 0 \\
\hline C-1 & $0.04 \times 10^{2}$ & $0.09 \times 10^{2}$ & $0.15 \times 10^{2}$ & $0.17 \times 10^{2}$ & $0.14 \times 10^{2}$ \\
\hline P-1 & $0.21 \times 10^{2}$ & $0.37 \times 10^{2}$ & $0.37 \times 10^{2}$ & $0.49 \times 10^{2}$ & $0.45 \times 10^{2}$ \\
\hline P-2 & $0.67 \times 10^{2}$ & $0.69 \times 10^{2}$ & $0.56 \times 10^{2}$ & $0.79 \times 10^{2}$ & $0.72 \times 10^{2}$ \\
\hline I-1 & $0.26 \times 10^{2}$ & $0.27 \times 10^{2}$ & $0.32 \times 10^{2}$ & $0.17 \times 10^{2}$ & $0.15 \times 10^{2}$ \\
\hline I-2 & $0.02 \times 10^{2}$ & 0 & $0.17 \times 10^{2}$ & $0.26 \times 10^{2}$ & $0.19 \times 10^{2}$ \\
\hline
\end{tabular}




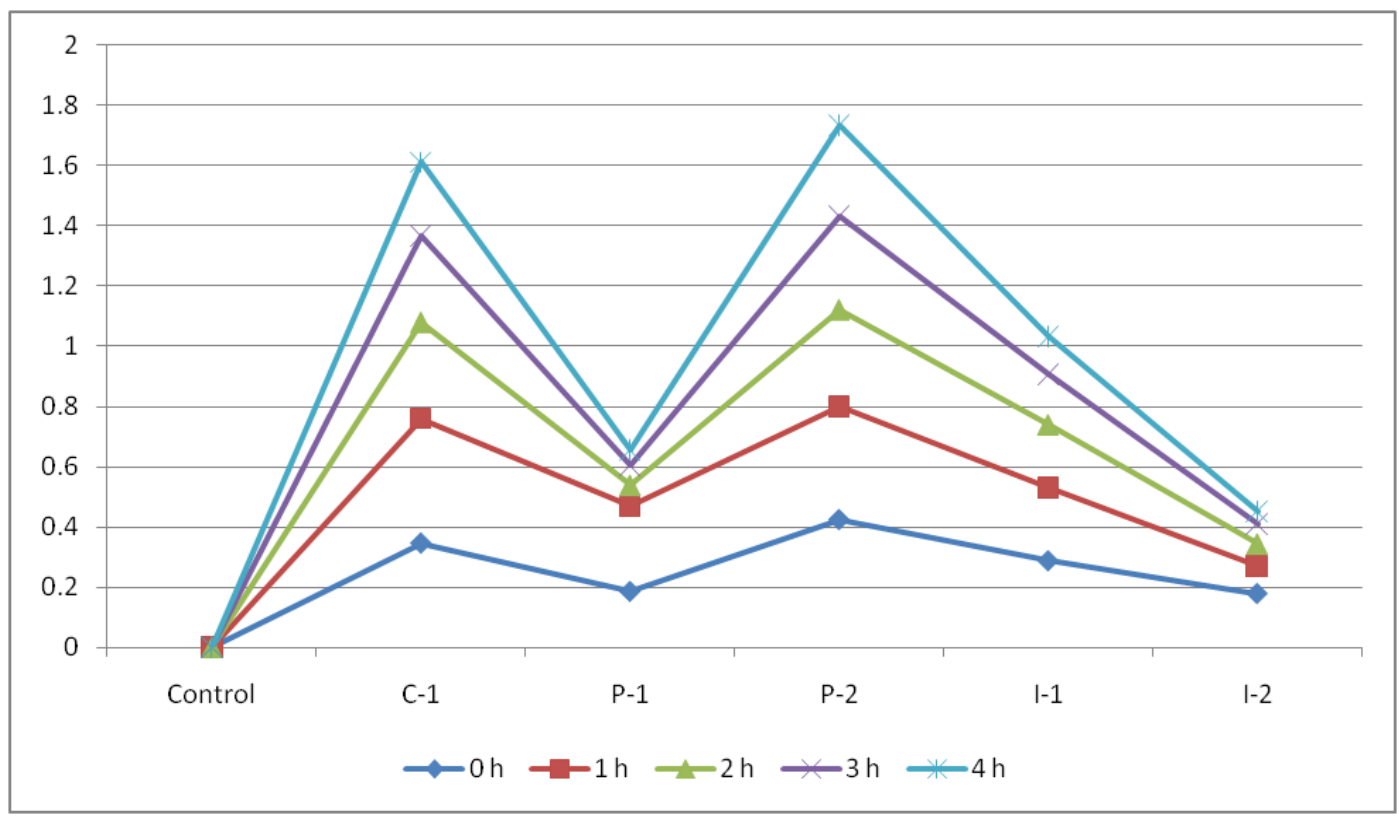

Figure.1 Screening of LAB isolates for tolerance to acidity $\mathrm{pH} 3.0$

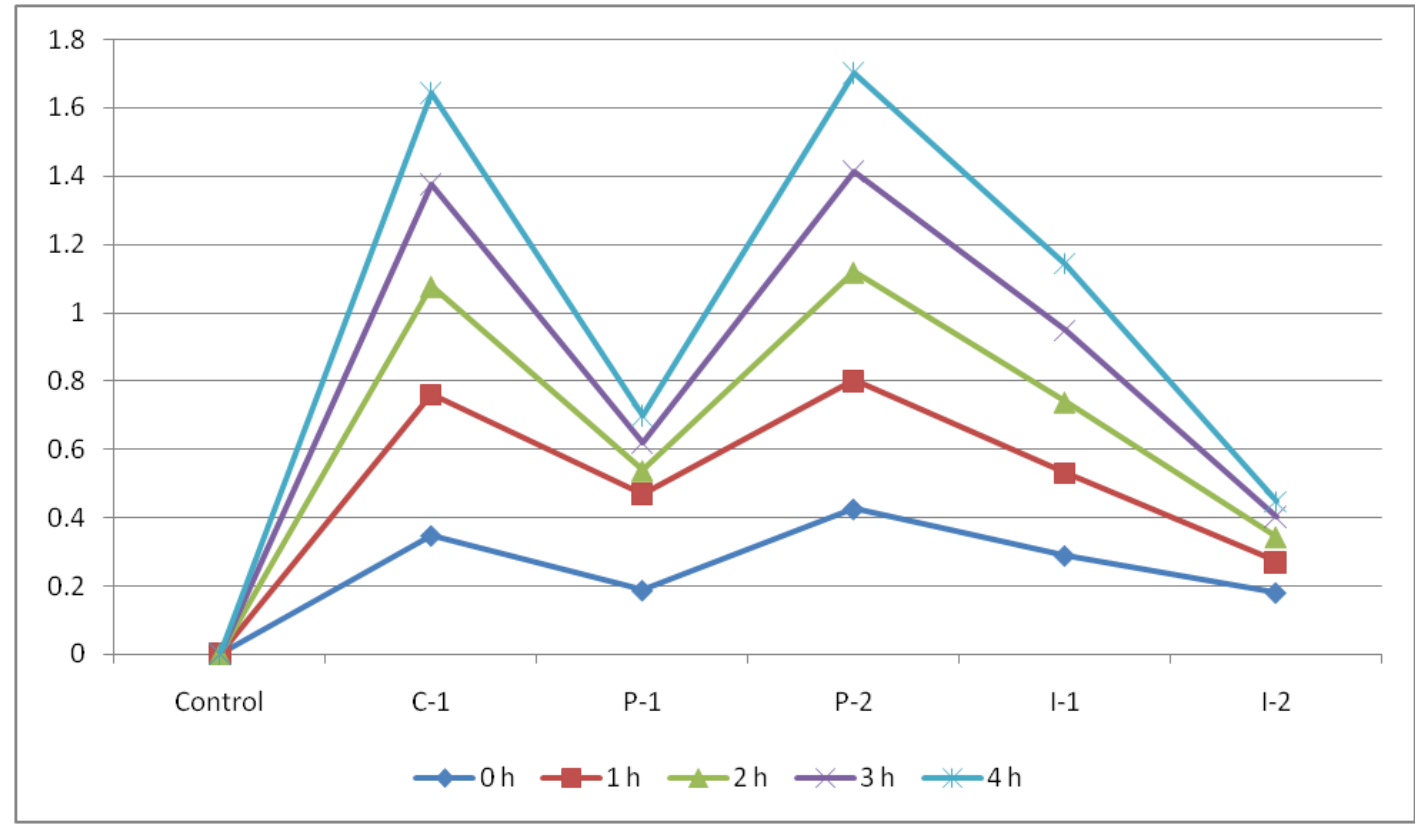

Figure.2 Screening of LAB isolates for tolerance to acidity $\mathrm{pH} 4.0$

Screening of LAB isolates at $3 \%$ bile salt concentration

All the isolates were tested for the tolerance to bile salt for $3 \%$. The isolate $\mathrm{P}-2$, was showing the ability to tolerate both $3 \%$ of bile salt concentrations. (Table 4 ). The highest growth of $0.79 \times 10^{2} \mathrm{CFU}$ were observed at 3 hours of incubation by P-2 followed by P-1 $\left(0.49 \times 10^{2} \mathrm{CFU}\right)$. All the other isolates did not show any significant tolerance to the bile salts. The concentration of $0.3 \%$ bile salts, which is critical to screen for human probiotics could resisit $58 \%$ of $L$. curvatus and all L. plantarum strains (Papamanoli et al., 2003). Bile salts affect the cell 
membranes of the microorganism, as they are composed of lipids and fatty acids. But some lactobacilli are able to hydrolyze bile salts with bile salt hydrolase enzyme, weakening their detergent effect (Erkkila and Petaja, 2000).

The probiotic properties of desirable bacteria are dependent on their ability to remain viable and to colonize the surface of human intestinal cells, thus a viable cell population of $10^{7}-10^{9}$ cells per day in necessary in order to provide any beneficial effects to develop in humans (Salminen et al., 1998). Probiotic lactic acid bacteria used as starter cultures in development of fermented food products.

Based on the test results the effective strain $\mathrm{P}$ 2 was identified as a probiotic bacteria. This LAB isolate was performing better in all the technological and probiotic characterization for utilizing to develop probiotic based fruit / milk drink.

\section{Acknowledgement}

The author thank Tamil Nadu Agricultural University, Agricultural College and Research Institute, Madurai for providing laboratory facilities to carry out this research work.

\section{References}

Erkkila, S., and Petaja , E. 2000. Screening of commercial meat starter cultures at low $\mathrm{pH}$ and in the presence of bile salts for potential probiotic use. Meat Science, 55: 297-300.

Garriga, M., Hugas, M., Gou, P., Aymerich, M. T., Arnau, J., and Monfort, J. M. 1996. Technological and sensorial evaluation of Lactobacillus strains as starter cultures in fermented sausages. International Journal of Food Microbiology, 32: 173-183.

Hammes, W. P. and D. Haller, 1998. Wiesinnvollist die anwendungvon probiotika in fleischwaren? .Fleischwirtschaft, 78: 301-306.

Hugas, M., Garriga, M., Aymerich, T., and Monfort, J. M. 1993. Biochemical characterization of lactobacilli from dry fermented sausages. International Journal of Food Microbiology, 18: 107113.

Jensen, Grimmer, Natersad and Axellson 2012. In vitro testing of commercial and potential lactic acid bacteria. International Journal of Food Microbiology, 153: 216-222.

Leeber, V and De Keersmaecker S C. 2010. Host interactions of probiotic bacterial surface molecules: comparison with commensals and pathogens. Nature Reviews Microbiology, 8: 171-184

Papamanoli, E., Tzanetakis, E., Litopoulou, E. and Kotzekidou, P. 2003. Characterization of lactic acid bacteria isolated from a Greek dry-fermented sausage in respect of their technological and probiotic properties. Meat Science, 65: 859-867.

Salminen, S., Deighton, M., Benno, Y., and Gorbach, S. 1998. Lactic acid bacteria in health and disease. In S. Salminen and A. von Wright (Eds.), Lactic acid bacteria (pp. 211-254). New York: Marcel Dekker.

Samelis, J., Maurogenakis, F., and Metaxopoulos, J. 1994. Characterization of lactic acid bacteria isolated from naturally fermented Greek dry salami. International Journal of Food Microbiology, 23: 179-196. 


\section{How to cite this article:}

Sivasankari Devi. T, B. Jeberli Prabina, M. Gomathy and Kumutha. K. 2020. Isolation and Characterization of Lactic acid bacteria from homemade fermented foods for probiotic applications. Int.J.Curr.Microbiol.App.Sci. 9(02): 1355-1362.

doi: https://doi.org/10.20546/ijcmas.2020.902.158 